\title{
The red and the black: neo-fascist inheritance in the electoral success of the Lega in Tuscany, Umbria, and Marche
}

\author{
Moreno Mancosu and Riccardo Ladini
}

\begin{abstract}
QUERY SHEET
This page lists questions we have about your paper. The numbers displayed at left are hyperlinked to the location of the query in your paper.

The title and author names are listed on this sheet as they will be published, both on your paper and on the Table of Contents. Please review and ensure the information is correct and advise us if any changes need to be made. In addition, please review your paper as a whole for typographical and essential corrections.

Your PDF proof has been enabled so that you can comment on the proof directly using Adobe Acrobat. For further information on marking corrections using Acrobat, please visit

http://journalauthors.tandf.co.uk/production/acrobat.asp;

https://authorservices.taylorandfrancis.com/how-to-correct-proofs-withadobe/

The CrossRef database (www.crossref.org/) has been used to validate the references. Changes resulting from mismatches are tracked in red font.
\end{abstract}

\section{AUTHOR QUERIES}

Q1 Please provide the keywords in Italian.

Q2 None of the following references are in the reference list, please provide complete details. • Salvini 2006 • Salvini 2008 • Salvini 2013.

Q3 Putnam et al. 1993 is not in the reference list. Please provide complete details.

Q4 Putnam et al. 1993 is not in the reference list. Please provide complete details.

Q5 Putnam et al. 1994 is not cited in the text. Please cite or delete reference.

Q6 Please provide the journal's volume number. 


\title{
The red and the black: neo-fascist inheritance in the electoral success of the Lega in Tuscany, Umbria, and Marche
}

\author{
Moreno Mancosu ${ }^{\mathrm{a}}$ and Riccardo Ladini ${ }^{\mathrm{b}}$ \\ ${ }^{\mathrm{a}}$ Torino, Italy; ${ }^{\mathrm{b}}$ Milan, Italy
}

\begin{abstract}
In 2018 Italian general elections, the Lega has dramatically increased its consensus in the 'red belt', the central area of the country traditionally ruled by centre-left parties. Pundits have argued that this performance can be attributed to the new leadership of Matteo Salvini, who changed the ideological location of the Lega by transforming it in a national right-wing party. This article hypothesizes that geographical trajectories of diffusion of the party are associated with the prevalence of a neo-fascist minority present in the region during the First Republic. By employing official electoral results at the municipality level, the article analyses the relationship between the percentages of votes for the M.S.I. in 1976 and the Lega in the 2006-2018 period in Tuscany, Umbria, and Marche. The neo-fascist inheritance results to be associated with the vote for the Lega only in 2018, after the change in the political discourse and leadership of the party.
\end{abstract}

\section{RIASSUNTO}

Nelle elezioni politiche italiane del 2018 la Lega ha notevolmente aumentato il suo consenso nella 'zona rossa', l'area centrale del Paese tradizionalmente amministrata dai partiti di centro-sinistra. I commentatori hanno sostenuto che questo risultato fosse da attribuirsi alla nuova leadership di Matteo Salvini, che ha modificato la posizione ideologica della Lega trasformandola in un partito nazionale di destra. Questo articolo ipotizza che le traiettorie geografiche di diffusione della Lega siano associate alla prevalenza di una minoranza neofascista presente nella 'zona rossa' durante la Prima Repubblica. Utilizzando i dati elettorali ufficiali a livello comunale, l'articolo analizza la relazione tra le percentuali di voto per il Movimento Sociale nel 1976 e per la Lega nel periodo 2006-2018 in Toscana, Umbria e Marche. L'eredità neo-fascista risulta essere associata al voto per la Lega soltanto nel 2018 , in seguito al cambiamento nella comunicazione politica e nella leadership del partito.

\section{Introduction}

In Italian political science literature, the role of the so-called 'leaguism' (Tarchi, 1998) has been deeply analysed since the early 1990s, when the appearance 
of the Lega Nord in the political spectrum contributed crucially to the end of the First Republic.

Since its birth, the party manifesto had been based on typical ethnoregionalist goals, such as the promotion of knowledge of local history and culture, and demands for the transfer of powers to local administrations (Agnew 1995; Tarchi 1998). During more than twenty-five years of presence in the Italian political landscape, the Lega has passed through several vicissitudes, by both gaining relevant shares of votes (for instance, in 1992 and 1996) and reaching very low levels of support (for instance, 2013 national elections). One of the steady characteristics of the trend of expansion and contraction of the movement, however, consisted of the boundaries inside which the voting pattern took place (Segatti and Vezzoni 2011). As pointed out by Passarelli and Tuorto (2012a, 420), 'the Lega not only symbolically evoked the role of territory in its political mission but also had a geographically well-defined electoral background since its establishment': even if we consider the party's strongest performances, relevant results were always confined in northern Italian regions, roughly until Emilia-Romagna (see Passarelli and Tuorto 2012a). The Lega, indeed, never succeeded in central regions, the so-called 'red belt', which had been dominated by centreleft parties since the immediate post-war period (Galli 1968; Sani 1976; Diamanti 2003; Anderlini 2007).

This consolidated pattern started to change substantially with the results of 2015 regional elections. In that occasion, the Lega obtained significant percentages in central regions, such as Tuscany, Umbria, and Marche, traditionally hostile to the party (D'Alimonte 2015). In those regions the Carroccio became the second party in the political spectrum, after the centre-leftist Partito Democratico, acquiring more than 250,000 votes with respect to 2014 European Elections. That figure was further reinforced in 2018 national elections, in which the consensus of the Lega showed an increase of about 600,000 votes compared to previous general elections (in 2013, the party obtained only 25,699 votes in Tuscany, Umbria, and Marche).

From the supply-side, we can at least find two explanations of this exploit: the first focuses on the change of leadership in the Lega (D'Alimonte 2015; Albertazzi et al. 2018). After over 20 years under the guidance of Umberto Bossi, in 2013 the leadership passed to Matteo Salvini, who progressively changed the discourse and the aims of the party (Albertazzi 2016). Indeed, the new course of the Lega led by Salvini is no more solely oriented to northern Italian regions. Instead, Salvini's efforts are aimed at creating an extreme-right-wing national party, focused on anti-immigrant and antiEuropean claims, similarly to Marine Le Pen's Front National in France (Brunazzo and Gilbert 2017). According to pundits and commentators, the nationalization process of the Lega led the party to become a much more viable political option for the centre-right electorate (Diamanti 2015). 
Combined with this interpretation, another political component of this success has been identified in the progressive loss of strength and appeal of the historical ally of the Lega, Forza Italia. The decrease of consensus of Berlusconi's party at the national level has left a free space in the right spectrum, leading to the positive result of the Carroccio.

By keeping in mind these supply-side explanations, our article aims at investigating the role of the political traditions in the 2018 success of the 'new' Lega in Tuscany, Umbria, and Marche. Our set of explanations will focus on the Lega as a party with a unique geographical history, in which the trajectories of its expansion are correlated with the traditional cleavages that have been present in the red belt since the first republic. Indeed, the red belt - far from being a monolithic region completely dominated by centre-left parties - presents several places in which a small, but fierce, and geographically clustered neo-fascist minority has been present since the First Republic. In this respect, our main hypothesis is that the strategy of the 'new' Lega, more related to extreme right-wing claims than regionalistic demands, might have led to a larger success in places where the neo-fascist minority had been stronger during the First Republic (Agnew 1992; Baccetti and Gabelli 1998).

To control for alternative explanations to the expansion of the Lega in the centre we will take into account characteristics that the party shares with other extreme right-wing parties around Europe and the responses that voters tend to give to those parties. In this respect, the literature provides at least two main explanations of these parties' support on the territory: the 'modernization losers' and the 'racial threat' explanations (Betz 1994; Beirich and Woods 2000; Bowyer 2008).

The aim of the article is not only confined in the analysis of a single casestudy. While many studies in electoral geography have focused on the electoral inheritance of the major subcultures, less attention has been provided to the electoral continuity of what we will call 'minority political traditions'. Our work aims to shed light on this aspect which can give a crucial contribution in explaining the territorial variance of parties' performance.

Results confirm our hypotheses, by showing that the success of the Lega proves to be stronger in areas particularly favourable to the neo-fascist minority during the First Republic. Moreover, it is argued that this phenomenon is somewhat new, since the correlation between the neo-fascist minority's and the Lega's vote share is no longer consistent when we take into account the Lega's outcomes in the three previous national elections held before the ideological shift operated by Salvini (2006, 2008, 2013).

The study also aims at contributing to the debate on the role of long-term historical patterns in shaping political attitudes and behaviours, which might 
be driven, among other things, by processes of behavioural (Acharya et al.

2018) and institutional path dependence (Putnam et al, 1993).

\section{Background}

Among the several vicissitudes having affected the Lega Nord (for more information see Diamanti 1993; Cartocci 1994; Cento Bull and Gilbert 2001; Passarelli and Tuorto 2009, 2012a), the last, and more important for our aims, concerns the turmoil that reset the leadership of the party in 2012. A fraud scandal hit directly the historical leader of the Lega, Umberto Bossi, who was forced to resign from his role of undisputed leader of the party (Albertazzi, 2016). After a brief interregnum managed by Roberto Maroni, in December 2013 the leadership of the Lega passed to a young leader of the party, Matteo Salvini.

Since the beginning of its office, Salvini characterized his political action further to the right wing with respect to Bossi's leadership. Several pundits have stressed that the actual aim of Salvini was to transform the old regionalist Lega into something new: a party radically rooted on the right-side of the political spectrum, that exploits with its rhetoric the anti-immigrant and antiEU sentiments that are largely present in the Italian population (Albertazzi 2016; Brunazzo and Gilbert 2017). Furthermore, Salvini's political action has been devoted to turning the Lega into a fully national party (Albertazzi et al. 2018), that could count on votes of people far from the traditional geographical boundaries of the original Lega.

As pointed out by Albertazzi et al. (2018), the Lega claims indeed moved from a mainly regionalist focus on autonomy and federalism to a national focus on nativism and protectionism. ${ }^{1}$ In such respect, the Lega's main enemies shifted from the national level, namely Rome and the Southern Italians, to the supranational one, namely the EU, Brussels bureaucrats, and the immigrants (Albertazzi et al. 2018). As a result, it is relevant to remember the attempts of Salvini to organize electoral committees also in Southern Italy. Another indirect proof of this double shift (to the right of the political spectrum and the south of the country) can be found in the factual collaborations (and joint mobilization) of the Lega with other extreme right nationalist groups (Albertazzi 2016).

According to Segatti and Vezzoni (2011), until the last electoral cycle, the electoral pattern of the Lega could be depicted as an expanding and contracting lung, confined to the northern regions of the country. In particular, they argued that when the political system proved to be more stable, the area of the consensus of the Lega became smaller, generally confined around its strongholds. In more turbulent political times, instead, the Lega came out from its traditional boundaries and spread its consensus in other areas, like the Western provinces of the Emilia-Romagna. 
Nonetheless, a first territorial change of the Lega dates back to 2008 election, when it doubled its share of votes in Emilia-Romagna (7.8 perc cent, against the 3.9 per cent in 2006, see Passarelli and Tuorto 2012a, 2018) which represents one of the four regions of the red belt (Galli 1968). Such support in that region was later confirmed both in 2009 European elections (11.1 per cent) and 2010 regional elections (13.7 per cent). In that period, scholars noticed a first sign of the nationalization of the Lega, which started to focus more on national than territorial issues (Diamanti 2009; Passarelli and Tuorto 2012a, 2012b). However, as table 1 shows, the support of the Lega in the other regions of the red belt was still irrelevant. In 2006, 2008, and 2013 elections the percentage of votes for the Lega Nord in Tuscany, Umbria, and Marche oscillated between 0.7 per cent and 2.2 per cent. In all the three elections, the performance of the Lega never exceeded the 10 per cent in any of the 618 municipalities. In those areas, the nationalization of the Lega brought beneficial effects since the European Elections of 2014, when the Lega doubled its preferences at the country-level compared to 2013 National elections (6.2 per centagainst 3.1 per cent in 2013). Later, the Lega succeeded beyond the wildest imagination of its supporters in 2015 regional elections, and furthermore in 2018 national elections, as reported in table 1. Such electoral outcomes represent, thus, a unique circumstance in the history of the party. Although the Lega proved to be marginally stronger in Umbria (20.2 per cent), its performance has been outstanding even in Tuscany and Marche (more than 17 per cent). In Tuscany, the party obtained more than 10 per cent of the valid votes in every municipality, and in at least one municipality onejin three voters chose the Lega, as well as in Umbria. ${ }^{2}$

Overall, while in Emilia-Romagna the expanding process of the Lega already started at least one decade ago (Passarelli and Tuorto 2012a, 2012b, 2018), in the other three regions of the red belt the Lega was an irrelevant competitor until the recent nationalistic turn. Thus, our article aims at explaining the pattern of this exploit of the Lega in Tuscany, Umbria, and Marche by employing an electoral geopolitics approach (Galli 1968).

Table 1. Descriptive statistics of Lega vote share by region (Tuscany, Marche, Umbria).

\begin{tabular}{|c|c|c|c|c|c|c|}
\hline & & \multirow[b]{2}{*}{$\%$} & \multicolumn{4}{|c|}{ vote share (municipalities' distribution) } \\
\hline & & & Mean & Dev.std & Min & Max \\
\hline Tuscany & LN-MpA 2006 & 1,1 & 1,2 & 0,7 & 0,0 & 5,3 \\
\hline \multirow[t]{3}{*}{$(\mathrm{N}=287)$} & LN 2008 & 2,0 & 2,2 & 1,1 & 0,3 & 6,7 \\
\hline & LN 2013 & 0,7 & 0,8 & 0,4 & 0,0 & 2,5 \\
\hline & Lega 2018 & 17,4 & 19,7 & 4,5 & 10,3 & 33,3 \\
\hline Marche & LN-MpA 2006 & 1,0 & 1,1 & 1,0 & 0,0 & 7,4 \\
\hline \multirow[t]{3}{*}{$(\mathrm{N}=239)$} & LN 2008 & 2,2 & 2,4 & 1,7 & 0,0 & 9,8 \\
\hline & LN 2013 & 0,6 & 0,7 & 0,5 & 0,0 & 3,4 \\
\hline & Lega 2018 & 17,3 & 19,5 & 4,8 & 8,4 & 49,3 \\
\hline Umbria & LN-MpA 2006 & 0,8 & 0,7 & 0,5 & 0,0 & 3,0 \\
\hline \multirow[t]{3}{*}{$(\mathrm{N}=92)$} & LN 2008 & 1,7 & 1,6 & 1,0 & 0,0 & 6,4 \\
\hline & LN 2013 & 0,7 & 0,6 & 1,0 & 0,0 & 9,6 \\
\hline & Lega 2018 & 20,2 & 21,6 & 4,3 & 7,2 & 33,9 \\
\hline
\end{tabular}




\subsection{The inheritance of political traditions}

Since seminal studies on electoral behaviour in Italy (Galli 1968; Sani 1976), the territory has played a crucial role in the explanation of vote choice. The strong territorial organization of the two mass parties, which characterized the Italian First Republic (Christian Democracy [D.C.] and Italian Communist Party [P.C.I.]) were indeed reflected in their political subcultures. Depending on the party hegemony in a specific area and other socio-economic characteristics, Italy was subdivided into geopolitical areas (like the red belt here analysed), which, even nowadays, are always taken into account when studying Italian voting behaviour.

The disappearance of the two main political parties at the end of the First republic hugely increased the attention on the Italian context among electoral geography scholars, interested in analysing the vote dynamics after the turmoil of the political system. Although in different ways, a territorial voting continuity between the First and Second republic parties emerged (Agnew 1995, 1996; Shin and Agnew 2002, 2007, 2008; Passarelli and Tuorto 2012a). Moreover, in addition to analysing territorial yoting dynamics in a relatively short time span, scholars also analysed the persistence of political traditions in terms of voting patterns. By analysing the relationship between the political tradition in the immediate post-war and the vote in 1972 at the municipality level, Sani (1976) argued that the D.C. had more consensus in places with a strong Catholic tradition, as well as the P.C.I. in municipalities with a strong communist or socialist tradition. Even though the role of the political tradition has been progressively losing its prominence, Vezzoni (2008) showed continuity between the political traditions and vote in 2006 elections, especially in contexts where the D.C. or the P.C.I. tradition was strong.

The study of the inheritance of the political traditions, however, has mainly focused on the major political subcultures. Nonetheless, even other political traditions were able to persist in contexts dominated by a major political subject (Galli 1968), therefore, as Sani (1976, p.394) suggests, 'search for contextual forces shaping political attitudes should not be limited only to the identification of the major political tradition of the larger community'. Also minority political traditions, indeed, could have had an enduring effect on voting behaviour. It has been stressed above that the red belt has been dominated by centre-left parties (the P.C.I. during the First Republic and the P. D.S./P.D. in the Second). One might ask where a right-wing section of the electorate comes from in such a left-wing region. Despite the striking and durable majority of left-wing ideology in the red belt, it is possible to notice sub-regional anomalies in which the support to the opposition parties has been always more pronounced. These clusters, already identified and investigated in previous studies (Agnew 1992; Baccetti and Gabelli 1998; Shin and Agnew 2002) can be seen as something that we can call minority political 
traditions, enclaves in which the socio/political environment is different with respect to the vast majority of other parts of the territory. Some of these clusters have been investigated in depth: for instance, various studies explained the presence of small landownership and the Lucca's status as an independent republic as an explanation for the P.C.I.'s inability to be supported in those provinces, and the resulting strength of centrist and rightwing parties (Dogan 1967; Agnew 1992). As a result, even the red belt is not a politically homogeneous region.

When analysing the electoral advancement of the Lega in Emilia-Romagna since 2008, Passarelli and Tuorto (2012a) observed that the performance of the Lega was stronger in municipalities where the D.C. obtained more electoral consensus during the First Republic, similarly to the voting pattern of the Lega in other northern regions. Our work will thus provide evidence to test whether this relationship exists even in the other red belt regions. The term 'opposition party', in the red belt, might not only refer to the Christian Democrats (that is, the main traditional centre-right party in the First Republic), but also to the more extremist Movimento Sociale Italiano Destra Nazionale (Italian Social Movement - National Right_[M.S.I.]). For decades, the M.S.I. has been the fourth force in the Italian political spectrum, but it was kept outside governmental offices because of its neo-fascist legacy (Ignazi 1994, 2003; Tassani 1990). We can thus say that the M.S.I. represented, during the First Republic, the main political reference for the extreme right electorate (Ignazi 1994). What this article argues is that the process of extremization of the Lega, combined with the dismantlement of the regional rhetoric in favour of more nationalistic and extreme right-wing claims of Salvini's party, could have convinced this radical right-wing tradition (rooted in places where the M.S.I. was stronger in the First Republic) to trust the new course of the nationalist Lega. Theoretically, we argue that the success of the Lega in the red belt can be successfully predicted by the distribution of extreme right-wing minority traditions that coexisted with the dominant leftwing majority since the First Republic. The minority neo-fascist tradition is thus expected to be reflected in the voting pattern for the new Lega.

A first, intuitive clue of this idea can be seen in figures $1-3$. The placement of the extreme right-wing minority tradition is in figure 1, where M.S.I. strength during the First Republic (namely, the percentage over eligible voters of the M.S.I. in the 1976 national elections) is mapped for the municipalities of Tuscany, Umbria, and Marche. ${ }^{3}$

As shown in the maps, the M.S.I. is stronger in the northern part of the Tuscany, and especially in the province of Lucca (see the upper-left section of the map). Moreover, the south-western part of the same region (the province of Grosseto) sees a significant performance of the party. For what regards Umbria and Marche, it is possible to see that the southern part of both the regions sees stronger support for M.S.I. (especially, the southern municipalities of the 


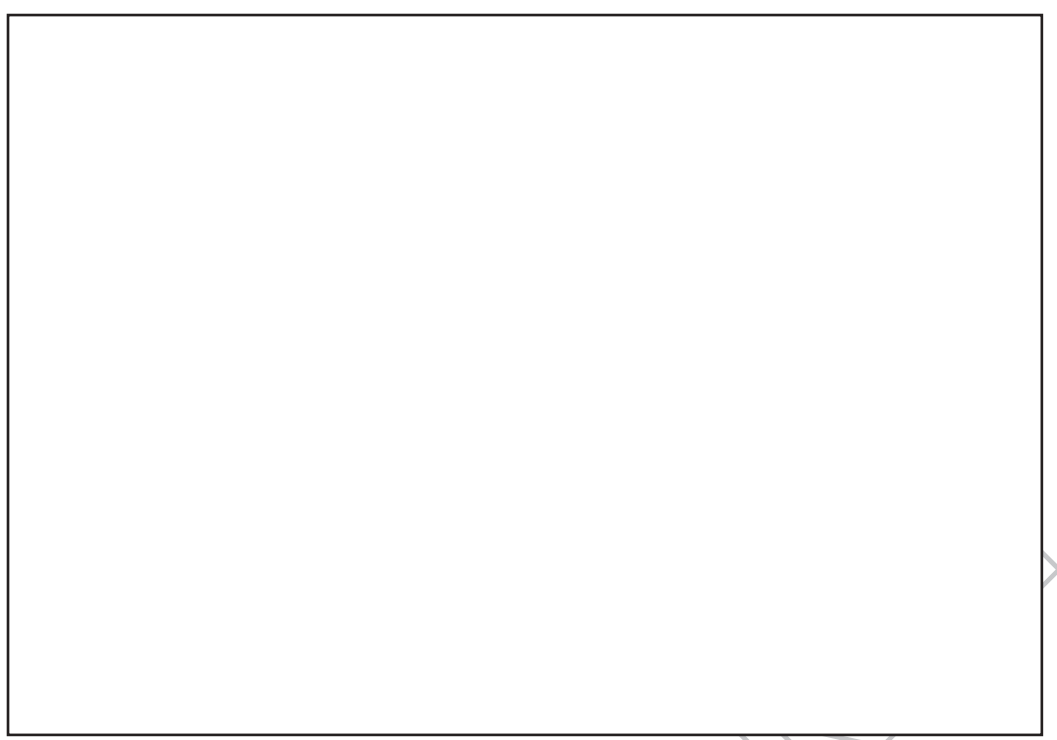

Figure 1. Spatial distribution of M.S.I. in 1976 national elections.

province of Perugia and Macerata). Figure 2 shows the distribution of the vote shares of the Lega in 2008. ${ }^{4,5}$ As it is possible to see, the thematic map does not reproduce at all the M.S.I. pattern. In 2008, the Lega proved stronger in places at the northern boundary of the three regions taken into consideration,

Figure 2. Spatial distribution of Lega Nord in 2008 national elections. 
consistently with the expansion-contraction trend of the party discussed by Segatti and Vezzoni (2011). Instead, the 2018 Lega map (figure 3) presents some analogies with that of the M.S.I. of 1976. The Lega seems slightly stronger in the centre-south of the region for what regards Umbria and (partially) Marche. The similarity between the two maps can also be seen in Tuscany (in the aforementioned provinces of Grosseto and Lucca). To sum, if the pattern of 2018 could partially resemble the one of M.S.I. in 1976, the pattern of 2008 seems pretty much uncorrelated with the map of M.S.I. in 1976.

\subsection{Alternative explanations: racial threat and modernization losers}

Although it seems that the explanation based on minority political traditions is intuitively consistent with the data presented above, other alternative explanations could confound the relation between Lega Nord exploit and neo-fascist minority enclaves. In the European literature, the study of determinants of the vote for extreme right-wing parties emphasizes the social background of these parties' support. Since early theories on working-class authoritarianism (Lipset 1981), it has been stated that working-class people are more likely to vote for extreme right-wing parties (Bowyer 2008). Betz (1994) suggests that the coming of a post-industrial society leads social risks (unemployment, poverty, etc.) to mainly overthrow on specific groups, in particular on working-class individuals, on the elder and people with low educational levels. Once the social system that used to guarantee protection 
to these parts of the population weakened, the members of these more fragile groups start to look for their political representatives among that parties that offer the simplest solution to their everyday problems. In this way, the 'modernization losers' (that is, people who, in a way or another fit imperfectly in the labor market or are at risk of poverty and social exclusion, see Evans 2005; Givens 2005) seem to be the most favourable environment in which an extremist right-wing party can find its supporters. Empirical proofs of the fact that, for instance, unemployed are more prone to support rightwing parties has been found both at the individual (Evans 2005; Givens 2005) and the aggregate level (Bowyer 2008; Rydgren and Ruth 2013; Goodwin, Ford, and Cutts 2013).

The second set of explanations, that of the 'racial threat' (Bowyer 2008; Ford and Goodwin 2010) is far more precise in defining the trademarks of the strategies of European extreme right-wing parties. The theory argues that, as long as the prevalence of immigrants (or ethnic minorities) increases in a place, as long as the natives' majority of that place perceives the minority as a threat to their privileges, becoming more hostile towards the minority. The perception of threat by the indigenous community and the conflict that follows can be triggered among various dimensions, such as the economic (conflicts concerning jobs, housing and welfare), or cultural one (language, traditions). Whatever the reason, it is possible to argue that when the size of one or more minority groups grows, the likelihood of a conflict increases. The empirical evidence of this argument presents mixed evidence: several studies (Givens 2005; Bowyer 2008) have found that the size of a particular minority increases the likelihood to vote for an extremist right-wing party. Other studies (e.g. Minkenberg and Schain 2003) did not find any clear relation.

\subsection{Hypotheses}

Our argument concerns the trajectories that the Lega took to gain support in the red belt. We have argued that nationalization and the radicalization of the party could have mobilized an extreme right-wing minority expected to vote other right-wing parties in the past and that now found the Lega as a valid alternative to those parties. If minority political traditions had an impact in the great electoral performance of the Lega in 2018, we should be able to identify a relationship between the geographical distribution of the neo-fascist tradition in the red belt and the penetration in the territory of the Lega in 2018. In particular, we expect that the stronger the M.S.l. performance has been during the First Republic, the stronger will be the Lega performance in 2018 national election (Hp1). This would be an indicator of the fact that the minority rightwing electorate in the zone recognized the nationalization of the new Lega message and accepted it. 
The argument exposed so far is based on the fact that the Lega has changed both in terms of communication and in ideological alignment. The nationalization process, under the leadership of Matteo Salvini, modified the political supply of the party and, in turn, could have modified perceptions that right-wing people of the red belt have towards the Lega itself. If this is true, the pattern we see in 2018 should be different with respect to what we have seen in previous elections (indirect evidence of this change has already been exposed when commenting on figures 1-3). Thus, our second hypothesis is that the electoral performance of the M.S.I. in the First Republic will not be correlated with the performance of the Lega Nord in national elections previous to 2018 (Hp2).

We have stressed above that the process of radicalization of the Lega can also be explained by contextual factors that favour xenophobic/right-wing parties around Europe. According to the theory of modernization losers, people who are threatened by processes of globalization and technological advancement, in particular, the unemployed, will be more likely to vote for a xenophobic party. Moreover, dealing with the Lega as a generic right-wing party, the racial threat argument states that people living in an environment with a high prevalence of immigrants can see a right-wing/xenophobic party as a reliable loudhailer of the conservation of their privileges, threatened by foreigners. Our two hypotheses will thus be tested by taking into account these two alternative explanations, whose operationalization will be explained in the next section.

\section{Data, methods and models}

All data analysed in this article are collected at the municipality level. Therefore, the ecological unit of analysis is the municipality, the most refined (in terms of number of voters) geo-referenced unit available. Electoral outcomes come from the Official Electoral Archive of the Italian Ministry of the Interior; they are therefore not affected by measurement error (except for some negligible material mistakes). The area analysed here includes the three regions in the red belt of Tuscany, Umbria, and Marche. Consistent with the hypotheses, the analyses will employ as dependent variables the percentages of votes (divided by eligible voters) of the Lega in 2006, 2008, 2013 and 2018 national elections. ${ }^{6}$

To operationalize the neo-fascist political tradition, which represents our main independent variable, following previous literature (Sani 1976; Vezzoni 2008) we employ the percentage of votes at the municipality level for the M.S. I. in 1976, about forty to fifty years before the election here analysed. Since we are dealing with a minority party, however, the simple correlation between the Lega and the M.S.I. could be misleading, since the M.S.I. coefficient could be moderated or even cancelled by the effect of other traditions. With this 
respect, thus, we must control for other possible confounders. Since it has been argued that the consensus for the Lega proved to be higher in areas where the D.C. tradition is stronger, in the model that follows we will add the strength of Christian Democrats in 1976 in every municipality, to take into account possible composition effect.

Alternative explanations of modernization losers and racial threat are operationalized by including among the control variables respectively the percentage of unemployed and foreigners, both measured in 2011 for each municipality. Moreover, we control for the age dependency ratio (the number of over-65 inhabitants divided by the under-14, multiplied by 100) and the logarithm of the population, measured in 2015 at the municipality level.

To test the geographical trajectories the Lega took for its exploit, we might employ O.L.S. linear regression models. However, regression analyses on spatially contiguous observations could lead to issues of spatial dependence, in which the structure of the correlation between observations follows a specific/spatial) neighboring structure. Including spatial dependence in our models solves two kinds of problem: the first, technical, argues that if not adequately considered, an ordinary least squares regression model can include spatially auto-correlated errors (a violation of O.L.S.' assumptions, which would lead to biased estimations). Secondly, the use of non-spatial models neglects a crucial characteristic of our data, that is, interdependence between ecological units.

Therefore, we have tested our hypotheses by employing spatial lag models, also referred to as spatial autoregressive models ([S.A.R.] see Ward and Gledistch 2008), which allow accounting for the spatial interdependence among observations by incorporating a spatial lag of the dependent variable. ${ }^{7}$ In detail, such a model adds a spatial autocorrelation term $(\rho W y)$ within the equation of a linear regression model, where $\rho$ is the spatial autoregressive coefficient, $W$ is the spatial weight matrix and $y$ is the dependent variable. The spatial lag operator (Wy) can be interpreted, if the weight matrix is row-standardized, as the average of the dependent variable on the neighbours of each ecological unit (Ward and Glitch 2008). Among the different alternatives in the design of the weight matrix W (Cliff and Ord 1970; Anselin 1988), we chose to define it as a $k$-nearest neighbour, with $k=4$. This because of the presence of noncontiguous municipalities (e.g. small islands) which, having no neighbours, would have been excised from the analysis. Thus, the spatial autoregressive coefficient $(\rho)$ measures the association between the dependent variable in the neighbours and the dependent variable in the single spatial units.

\section{Results}

Table 2 shows the results of the four spatial lag models. In Model 1, the dependent variable is represented by the share of valid votes for the Lega in 2018 general election, while in Model 2, 3, and 4 the dependent variable is the 
Table 2. Spatial lag models for the study of Lega Nord performances in general elections in the red belt.

\begin{tabular}{lcccc}
\hline & \multicolumn{3}{c}{ Lega \% } \\
\cline { 2 - 5 } & Model 1 & Model 2 & Model 3 & Model 4 \\
& 2018 & 2013 & 2008 & 2006 \\
\hline MSI '76 \% & $0.32^{* * *}$ & $-0.02^{*}$ & -0.04 & -0.01 \\
& $(0.09)$ & $(0.01)$ & $(0.03)$ & $(0.01)$ \\
DC '76 \% & $0.17^{* * *}$ & $0.006^{* *}$ & $0.02^{* * *}$ & $0.008^{* *}$ \\
& $(0.02)$ & $(0.003)$ & $(0.01)$ & $(0.003)$ \\
Foreigners \% & $0.09^{*}$ & 0.07 & $0.04^{* * *}$ & $0.02^{* * *}$ \\
& $(0.05)$ & $(0.07)$ & $(0.01)$ & $(0.01)$ \\
Unemployment \% & -0.03 & -0.04 & 0.06 & $0.07^{* *}$ \\
& $(0.02)$ & $(0.03)$ & $(0.06)$ & $(0.04)$ \\
Age dependency ratio & -0.002 & $-0.0007^{* * *}$ & $-0.0010^{*}$ & $-0.008^{* * *}$ \\
& $(0.002)$ & $(0.0002)$ & $(0.0006)$ & $(0.003)$ \\
Population (logarithm) & $-0.42^{* * *}$ & -0.01 & -0.04 & $-0.06^{*}$ \\
& $(0.16)$ & $(0.02)$ & $(0.05)$ & $(0.03)$ \\
Region: Tuscany (ref. Marche) & $2.37^{* * *}$ & $0.10^{*}$ & 0.17 & $0.21^{* * *}$ \\
& $(0.40)$ & $(0.06)$ & $(0.13)$ & $(0.08)$ \\
Region: Umbria & $2.69^{* * *}$ & -0.03 & $-0.34^{* *}$ & $-0.22^{* *}$ \\
& $(0.53)$ & $(0.07)$ & $(0.17)$ & $(0.10)$ \\
Constant & $10.40^{* * *}$ & $0.79^{* * *}$ & 0.87 & 0.70 \\
& $(2.15)$ & $(0.28)$ & $(0.64)$ & $(0.38)$ \\
Rho & $0.22^{* * *}$ & $0.13^{* *}$ & $0.35^{* * *}$ & $0.21^{* * *}$ \\
& $(0.05)$ & $(0.06)$ & $(0.05)$ & $(0.05)$ \\
Observations & 618 & 618 & 618 & 618 \\
$\mathrm{R}^{2}$ & 0.27 & 0.05 & 0.15 & 0.10 \\
\hline
\end{tabular}

Note: ${ }^{* *} \mathrm{p}<0.01,{ }^{* *} \mathrm{p}<0.05,{ }^{*} \mathrm{p}<0.1$

share of valid votes for the Lega in 2013, 2008, and 2006 elections. First, since the rho coefficient is always positive and significant, for every election analysed we provide empirical evidence towards the presence of spatial dependence in the percentage of votes for the Lega in contiguous municipalities. ${ }^{8}$

For what concerns the effects of neo-fascist minority tradition, the strength of the M.S.I. leads to significantly increased percentages of the Lega in 2018 (see Model 1). Net of the other variables, a 1-percentage point increase in the share of votes to M.S.I. in 1976 leads on average to an increase of the share of the vote to the Lega in 2018 of 0.32 percentage points. The coefficient provides empirical evidence to Hypothesis 1 .

According to our expectations, the relation should not hold in previous elections, in which the Lega was less concerned to present itself as a national, right-wing party. Model 2, 3, and 4 show indeed that M.S.I. coefficient, when the dependent variable is 2013, 2008, and 2006 Lega performance, is always negative, and even statistically significant at 0.10 level in 2013. While 2018 Salvini's Lega performance seems to be driven by neo-fascist minority tradition, the same does not apply for Bossi's (and Maroni's) old Lega. Therefore, empirical data confirm also Hypothesis 2. ${ }^{9}$

Differently from neo-fascist tradition, a stronger D.C. tradition always leads to higher support for the Lega Nord in the red belt, at least in the period 
2006-2018. This finding is consistent with previous analyses on EmiliaRomagna, the only 'red-belt' region where the Lega had obtained a not irrelevant consensus even before the 2013-2018 electoral cycle (Passarelli and Tuorto 2012a).

When looking at the alternative explanations of the Lega's vote, no clear evidence emerges in supporting the modernization losers' argument. Only in 2006, a higher unemployment rate seems to be associated with a higher consensus for the Lega Nord. The local prevalence of foreigners, on the contrary, increases Lega Nord strength in the red belt, even if slightly - an increase of 1 percentage point in the foreigners' prevalence increases the strength of the Lega by 0.09 percentage points in 2018 . We can thus conclude that results are consistent with the racial threat argument, even if the coefficient suggests a slight correlation.

\section{Discussion and conclusions}

In 2018, the Lega over-performed in several Italian regions with respect to previous elections, even in a part of the country which has been largely dominated by centre-left parties and has never provided support for the Carroccio. Although this anomaly with respect to the past has been explained by supply-side factors (the nationalization of the new Lega of Matteo Salvini and the drop in the support for its historical ally, Berlusconi's Forza Italia), this article aimed at studying whether political traditions played a role in the explanation of the territorial distribution of the Lega's vote.

Notwithstanding, our case study does not focus on the role of the major political subcultures, but with the 'black', neo-fascist minority tradition within a context historically dominated by the 'red' subculture. After having stated the process of radicalization and nationalization operated by the new leader of the Lega, Matteo Salvini, we hypothesized that the Lega could have spread in the red belt selectively among the cluster of support that the neo-fascist minority had in the First Republic. We argued that this minority political tradition reacted to the ideological shift of the 'new' Lega, by contributing to the success of the Carroccio in the 2018 Elections. As the regression models presented in the previous paragraph show, the effect of the M.S.I. tradition, the political reference of extreme-right in the First Republic, is large and significant. Net of several variables measured at the municipal level, among which the percentage of immigrants living in the municipality, the unemployment rate, and the percentage of votes for the D.C. in 1976, a 1 percentage point higher vote share for the M.S.I. in 1976 is associated to a 0.32 percentage points higher vote share for the Lega in 2018.

Results become even more evident if we consider, as dependent score, the spatial distribution of the Lega in national elections before Matteo Salvini's 
leadership. In this (as well as in 2006 and 2013 ones). At that time, however, the ideological switch was not yet performed, and the old leader's rhetoric was far more bounded into the limits of an ethno-regionalist ideology (less interesting for an electorate of the centre of the country). In this situation, the relation between the neo-fascist minority and the distribution of vote for the Lega in 2006, 2008, and 2013 is not significant, and the driving tradition is the Christian Democrat one measured by means of the percentage of vote for the D.C. in 1976, which proves to be positively associated with the vote for the Lega also in 2018 election.

Finally, we attempted to interpreting the Lega as a generic extreme rightwing party, and argued consistently that its uneven geographical distribution could be due to characteristics of the local context, such as the unemployment rate and the percentage of immigrants in the local environment: the literature shown that these two predictors could be connected with social mechanisms (respectively 'modernization losers' and 'racial threat') that could increase the voting likelihood for extreme right-wing parties (Bowyer 2008; Ford and Goodwin 2010). Regression models presented in the previous paragraph provided (little) evidence compatible with the sole racial threat argument.

Our results need to be taken with caution. First, we are conscious that no causal claims can be assessed and mechanisms explaining the success of the Lega cannot be tested through the data here employed. We just aimed to provide empirical evidence to two theoretically framed hypotheses, using ecological correlations. Second, this work does not attempt at explaining why the Lega obtained such an outstanding performance in the red belt in the 2018 elections. M.S.l. performance in the red belt was, on average, rather weak during the First Republic; therefore, it is unlikely that such a minority tradition represents the main driver of the recent success of the Lega. Third, analyses refer only to three regions of the red belt; thus, we cannot draw any conclusion towards the neo-fascist inheritance on the vote for the Lega Nord in other regions. If the Lega will continue in its process of electoral expansion, future research is expected to test our hypotheses even in other centre regions and in southern regions, by focusing on the areas where the M.S.I. political tradition was stronger than in any provinces of the red belt.

Our contribution provides new insights on the territorial distribution of the vote for the Lega. In this respect, we analyse whether minority political traditions which proved to be stronger in certain places persist and are related to the actual voting patterns. Despite the electoral earthquake and the unprecedented volatility which characterized both 2013 and 2018 national elections, as well as the progressive loss in the explanatory power of traditional cleavages when analysing voting behaviour, territorial patterns of vote seem somehow to persist, meaning that political traditions can still affect voting behaviour. More interestingly, our findings suggest a certain 
dynamicity of the effects of political traditions that adapt to the transformations of the electoral supply. In addition, the focus on the inheritance of the minority political traditions represents a promising perspective in the study of voting behaviour, which actualizes Sani's (1976) arguments.

More in general, the persistence of voting behaviour and political attitudes over time (and, plausibly, generations) can contribute to the debate on the role that long-term historical patterns have on human behaviour. Our evidence might be intended as consistent with, at least, one out of two social mechanisms that received increasing interest in recent years. The first is what has been lately defined as 'behavioural path dependence': by relying on studies of interpersonal communication, Acharya et al. (2018) have argued that the intergenerational transmission of political attitudes is able to remain stable for decades, and even centuries. This argument is partially related with the mechanism of the 'institutional path dependence' (Putnam et al.1993 ). By borrowing and adapting it, we might hypothesize that the presence in certain areas of local neo-fascist institutions (e.g. M.S.I. clubs, or 'sezioni') during the First Republic might have left in part of the population living in those areas a highly resilient sense of belonging to the minority sub-culture. Only future research will aim to understand how much those mechanisms are actually able to explain political change, both in Italy and in other countries.

\section{Notes}

1. Nonetheless, even when the political rhetoric of the Lega was more focused on secessionist goals, its voters showed similar levels of national identity compared to other Italian people (Segatti and Guglielmi 2012).

2. In addition to the shift of the political supply operated by the new leadership, several studies have argued that the success of the Lega is characterized by the correspondent defeat of Berlusconi's creature, Forza Italia, which obtained its historical minimum in those regions in 2015 regional elections (D'Alimonte 2015; Corbetta et al. 2015). As other studies stressed, by means of the technique of ecological inference, in 2015 regional elections the Lega increases its support in the red belt with respect to the previous election (2014 European Election) mainly to the expenses of Forza Italia's voters and marginally of other centreright parties, such as the right-wing Fratelli d'Italia (Corbetta et al. 2015). Similar outcomes are detected when analysing the electoral flows to the Lega Nord in 2018 national elections from votes in 2013 elections (Paparo and Cataldi 2018). Overall, it emerges clearly how the party that is mainly affected by the Lega's rise is indeed Berlusconi's Forza Italia.

3. To highlight and compare the areas where the Lega had on average a stronger (or weaker) performance, we used the same colour graduation in the two maps of the Lega in 2008 and 2018 elections. Nonetheless, as the legends show, the classes of percentages of vote corresponding to the same colour vary between the two maps.

4. To show the spatial distribution of the votes for the Lega before Matteo Salvini's leadership, we provided data coming from 2008 national election, because of 
the higher variabilities among municipalities than in 2006 and 2013 elections, as table 1 shows. Notwithstanding, similar patterns of the spatial distribution of the Lega are found even when considering 2006 and 2013 data. Results are available upon request.

5. The employment of measures concerning different elections (1976, 2006, 2008, 2013,2018 ) requests some small administrative adjustments to the structure of the municipalities. Over time, indeed, some municipalities merged, others have been split. The issue (which involves a small number of cases) has been managed by finding a least common geographical structure that could preserve the structure of the municipalities in 2013 Elections. Therefore, the number of statistical units included in the analyses is slightly higher than the number of municipalities of Tuscany, Umbria, and Marche in 2018.

6. Starting from 2016, some of the municipalities included in the analysis have merged together, therefore the most recent population data unique to every municipality refer to 2015 .

7. To empirically test the presence of spatial dependence, for the choice of the model we have run Lagrange multiplier tests which compare O.L.S. with spatial models (Anselin et al. 1996). Spatial lag models proved to be largely preferable than O.L.S. ones. In addition, spatial lag models were found to be slightly more appropriate than other spatial regression models, namely spatial error models, to fit our data. Results are available upon request.

8. All the models have also been estimated without the spatial autocorrelation term. Compared with O.L.S. models, in all the cases spatial lag models proved to increase the fit ( $p$-values of log-likelihood ratio tests $<0.05$ ). The output of the $O$. L.S. models is available under request.

9. Figure $A 1$ in the Appendix provides further evidence of our hypothesis. Even when analysing regional elections (in Tuscany, Marche, and Umbria), spatial lag models show that while in 2015 the relation with the M.S.I. tradition and the share of votes for the League is positive and significant, the same does not apply in 2010. Moreover, in 2010 the relation proves to be negative.

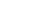


Anderlini, F. 2007. "Una frontiera italiana." II Mulino 56 (4): 644-652.

Anselin, L. 1988. Spatial Econometrics: Methods and Models. Dordrecht: Kluwer Academic.

Anselin, L., A. K. Bera, R. Florax, and M. J. Yoon. 1996. "Simple Diagnostic Tests for Spatial Dependence." Regional Science and Urban Economics 26 (1): 77-104.

Baccetti, C., and M. Gabelli. 1998. "Una prima falla nella Toscana rossa? La vittoria del centro-destra nelle elezioni comunali del 27 aprile 1997 a Grosseto." Quaderni dell'Osservatorio Elettorale 40 (2): 1-37.

Beirich, H., and D. Woods. 2000. "Globalisation, Workers and the Northern League." West European Politics 23 (1): 130-143.

Betz, H. G. 1994. Radical Right-Wing Populism in Western Europe. New York: St. Martin's Press.

Bowyer, B. 2008. "Local Context and Extreme Right Support in England: The British National Party in the 2002 and 2003 Local Elections." Electoral Studies 27 (4): 611-620.

Brunazzo, M., and M. Gilbert. "2017. Insurgents Against Brussels: Euroscepticism and the Right-Wing Populist Turn of the Lega Nord Since 2013." Journal of Modern Italian Studies 22 (5): 624-641.

Cartocci, R. 1994. Fra Lega e Chiesa. Bologna: il Mulino.

Cento Bull, A., and M. Gilbert. 2001. The Lega Nord and the Northern Question in Italian Politics. New York: Palgrave.

Corbetta, P., A. Pedrazzani, L. Pinto, and R. Vignati. 2015. Elezioni regionali 2015: I flussi elettorali a La Spezia, Padova, Livorno, Perugia, Napoli, Salerno, Foggia. Bologna: Istituto Cattaneo.

Cliff, A. D., and J. K. Ord. 1970. "Spatial Autocorrelation: A Review of Existing and New Measures with Applications." Economic Geography 46 (2): 269-292.

D'Alimonte, R. 2015. "Grillo resta secondo partito, Lega prima nel centrodestra." In Dopo la luna di miele. Le elezioni comunali e regionali fra autunno 2014 e primavera 2015, edited by Paparo, A., and M. Cataldi, 229-232. Roma: Centro Italiano di Studi Elettorali.

Diamanti, I. 1993. "La lega, imprenditore politico della crisi. origini, crescita e successo delle leghe autonomiste in Italia." Meridiana 16: 99-133.

Diamanti, I. 2003. Bianco, rosso, verde ... e azzurro. Mappe e colori dell'Italia politica. Bologna: ir Mulino.

Diamanti, 1. 2009. "Se il carroccio diventa una Lega nazionale." La Repubblica, December 13

Diamanti, I. 2015. "Salvini-Le Pen, relazioni pericolose." La Repubblica, May 18.

Dogan, M. 1967. "Political cleavages and social stratification in France and Italy." In Party Systems and Voter Alignments, edited by S. M. Lipset and S. Rokkan, 129-195. New York: The Free Press.

Evans, J. A. J. 2005. "The Dynamics of Social Change in Radical Right-Wing Populist Support." Comparative European Politics 3 (1): 76-101.

Ford, R., and M. J. Goodwin. 2010. "Angry White Men: Individual and Contextual Predictors of Support for the British National Party." Political Studies 58 (1): 1-25.

Galli, G., ed. 1968. II comportamento elettorale in Italia: Un'indagine ecologica sulle elezioni in Italia tra il 1946 e il 1963. Bologna: il Mulino.

Givens, T. E. 2005. Voting Radical Right in Western Europe. New York: Cambridge University Press. 
Goodwin, M., R. Ford, and D. Cutts. 2013. "Extreme Right Foot Soldiers, Legacy Effects and Deprivation: A Contextual Analysis of the Leaked British National Party (BNP) Membership List." Party Politics 19 (6): 887-906.

Ignazi, P. 1994. Postfascisti? La trasformazione del Movimento sociale in Alleanza nazionale. Bologna: il Mulino.

Ignazi, P. 2003. Radical Extreme Right Parties in Western Europe. Oxford: Oxford University Press.

Lipset, S. M. 1981. Political Man. Baltimore, MD: Johns Hopkins University Press.

Minkenberg, M., and M. Schain. 2003. "The Front National in context: French and European dimensions." In Right-Wing Extremism in the Twenty-First Century, edited by P. H. Merkl and L. Weinberg, 161-190. London: Frank Cass Publishers.

Paparo, A., and M. Cataldi. 2018. "A Prato i voti di Monti non premiano Renzi, e il centrosinistra cede al centrodestra." Centro Italiano di Studi Elettorali, March 8. https://cise.luiss.it/cise/2018/03/08/a-prato-i-voti-di-monti-non-premiano-renzi -e-il-centrosinistra-cede-al-centrodestra/

Passarelli, G., and D. Tuorto. 2009. "La Lega Nord oltre il Po." II Mulino 58 (4): 663-670.

Passarelli, G., and D. Tuorto. 2012a. "The Lega Nord Goes South:The Electoral Advance in Emilia-Romagna: A New Territorial Model?" Political Geography 31 (7):419-428.

Passarelli, G., and D. Tuorto. 2012b. "'Green ceramics' at Sassuolo. A Study on the Lega Nord in Emilia-Romagna." Etnografia e ricerca qualitativa 2, 261-288.

Passarelli, G., and D. Tuorto. 2018. La Lega di Salvini. Bologna: il Mulino.

Putnam, R. D., R. Leonardi, and R. Y. Nanetti. 1994. Making Democracy Work: Civic Traditions in Modern Italy. Princeton, NJ: Princeton University Press.

Rydgren, J., and P. Ruth. 2013. "Contextual Explanations of Radical Right-Wing Support in Sweden: Socioeconomic Marginalization, Group Threat, and the Halo Effect." Ethnic and Racial Studies 36 (4): 711-728.

Sani, G. 1976. "Political Traditions as Contextual Variables: Partisanship in Italy." American Journal of Political Science 20 (3): 375-405.

Q@ Segatti, P., and C. Vezzoni. 2011. "Alla ricerca del limes padano." LIMES (2): 59-70.

Segatti, P., and S. Guglielmi. 2012. "Padani o italiani? I sentimenti nazionali degli elettori leghisti." II Mulino 61 (3): 431-438.

Shin, M. E., and J. A. Agnew. 2002. "The Geography of Party Replacement in Italy, 1987-1996." Political Geography 21 (2): 221-242.

Shin, M. E., and J. A. Agnew. 2007. "The Geographical Dynamics of Italian Electoral Change, 1987-2001." Electoral Studies 26 (2): 287-302.

Shin, M. E., and J. A. Agnew. 2008. Berlusconi's Italy: Mapping Contemporary Italian Politics. Philadelphia, PA: Temple University Press.

Tarchi, M. 1998. "The Lega Nord." In Regionalist Parties in Western Europe, edited by L. De Winter and H. Tursen, 143-157. London: Routledge.

Tassani, G. 1990. "The Italian Social Movement: From Almirante to Fini." Italian Politics 4: 124-145.

Vezzoni, C. 2008. "Contesto territoriale e voto nelle elezioni del 2006. Un approccio multilivello." Polis 22 (2): 193-220.

Ward, M. D., and K. S. Gledistch. 2008. Spatial Regression Models. Los Angeles, CA: Sage 
Table A1. Spatial lag models for the study of Lega Nord performances in 2010 and 2015 regional elections in the red belt.

\begin{tabular}{|c|c|c|}
\hline & \multicolumn{2}{|c|}{$\%$ Lega } \\
\hline & 2015 & 2010 \\
\hline MSI '76 \% & $\begin{array}{l}0.15^{* * * *} \\
(0.04)\end{array}$ & $\begin{array}{l}-0.11^{* * * *} \\
(0.04)\end{array}$ \\
\hline DC '76 \% & $\begin{array}{l}0.03^{* * * *} \\
(0.01)\end{array}$ & $\begin{array}{l}0.03^{* * *} \\
(0.01)\end{array}$ \\
\hline Foreigners \% & $\begin{array}{l}0.07^{* * * *} \\
(0.02)\end{array}$ & $\begin{array}{l}0.07^{* * * *} \\
(0.02)\end{array}$ \\
\hline Unemployment \% & $\begin{array}{l}-0.09 \\
(0.09)\end{array}$ & $\begin{array}{c}0.03 \\
(0.08)\end{array}$ \\
\hline Age dependency ratio & $\begin{array}{l}-0.003^{* * *} \\
(0.001)\end{array}$ & $\begin{array}{l}-0.003^{* * *} \\
(0.001)\end{array}$ \\
\hline Population (logarithm) & $\begin{array}{c}0.04 \\
(0.07)\end{array}$ & -0.07 \\
\hline Region: Tuscany (ref. Marche) & $\begin{array}{l}2.25^{* * *} \\
(0.20)\end{array}$ & \\
\hline Region: Umbria & $\begin{array}{l}1.77^{* * *} \\
(0.26)\end{array}$ & $\frac{-0.82^{* * *}}{(0.23)}$ \\
\hline Constant & $\begin{array}{l}3.06^{* * *} \\
(0.98)\end{array}$ & $\begin{array}{l}2.63^{* * *} \\
(0.89)\end{array}$ \\
\hline Rho & $\begin{array}{l}0.12^{* *} \\
(0.05)\end{array}$ & $\begin{array}{l}0.20^{* * *} \\
(0.05)\end{array}$ \\
\hline $\begin{array}{l}\text { Observations } \\
\text { Nagelkerke } \mathrm{R}^{2}\end{array}$ & $\begin{array}{l}618 \\
0.26\end{array}$ & $\begin{array}{l}618 \\
0.17\end{array}$ \\
\hline
\end{tabular}

